\title{
Modelling the difficult airway - how real is faking it?
}

\author{
Edward Crosby MD
}

I $\mathrm{N}$ this issue of the Journal, Agrò et al. report their results of a clinical investigation evaluating the use of the Trachlight ${ }^{\mathrm{TM}}$ lighted stylet in a simulated difficult airway. ${ }^{1}$ They conclude that the Trachlight ${ }^{\mathrm{TM}}$ is a safe and effective tool applied to the management of patients who have a simulated difficult airway. The authors simulated a difficult airway by using a direct laryngoscope to create a Grade 3 view, while concurrently employing the Trachlight $^{\mathrm{TM}}$ to facilitate tracheal intubation. This study is one of many reported which have assessed the role of new technology in managing difficult airways. In these reports the difficult airway is occasionally real but is more often simulated and the relevance of such publications to clinical practice is not always clear.

Airway management is both a cognitive and a technical exercise. Clearly, the practitioner has to have a sense of what is appropriate in a given scenario (the cognitive aspect). This implies a recognition and integration of the clinical situation and the subsequent implementation of a targeted clinical strategy likely to be effective in managing the identified scenario. At some point in the intervention, the process becomes predominantly technical and the imperative is to act quickly and effectively. The elements of the technical intervention should have long ago been isolated and practiced - this is the handicraft of our specialty.

Training devices and patient simulations are used for airway skills training, for assessment of new tools and techniques and for the re-evaluation of older tools and strategies for airway management. They are probably more important currently for training than they have been in the past. For a variety of reasons (including reduced allowable hours of work and increasing numbers of didactic sessions), trainees are spending less time in operating rooms and are exposed to a smaller number of patients during training. ${ }^{2}$ Uncommon conditions, such as a difficult airway, will thus be encountered less frequently over the course of training. There is also data which suggest that new tools are not widely nor commonly used by clinical teachers; $; 34$ thus they are likely to be reluctant to have trainees "experimenting" on patients who will derive no direct benefit from participation in the training venture and may actually experience adverse events during such episodes. ${ }^{5}$ The widespread use of the laryngeal mask has also decreased both the opportunities for and the experience level of trainees with other airway interventions. For these reasons and others, there is a need now to enhance and concentrate the training experience; training devices and patient simulations subserve this need.

There is no question that the use of devices in airway training is an effective strategy to develop and enhance technical skills related to airway management. Basic and even advanced airway skills may be acquired and practiced on airway models before the skills are utilized in patient care. Intubation mannequins for direct laryngoscopy and the mechanical models for flexible endoscopy training are examples of such devices determined to have utility. In these training sessions, the intervention opportunities are unlimited, repetition can be endless, and mistakes carry no untoward patient consequences. Repetition is important as upwards of one hundred events may be necessary to achieve reliable success rates when learning airway interventions. ${ }^{6,7}$ This is increased in situations where the interventions are deemed difficult. ${ }^{8}$ There is also good evidence to support the hypothesis that technical skills training is facilitated by the use of a graduated training program employing airway devices and patient simulations; better outcomes are achieved when those skills are subsequently applied to patient care. Trainees who undergo such graduated skill training experience higher rates of success than those trained in a more traditional (see one, do one) fashion. ${ }^{9}$

With respect to determining the utility of new devices in airway management, it is likely that we will continue to be reliant on the use of patients as test subjects. In this context, there is usually no modelling, but rather two straightforward questions are asked (and hopefully answered); 1) does the device work? and 2)

From the Department of Anesthesiology, University of Ottawa, Ottawa, Ontario, Canada.

Address correspondence to: Dr. Edward Crosby, Department of Anesthesiology, Ottawa Hospital - General Site, Room 2600,501

Smyth Road, Ottawa, Ontario K1H 8L6, Canada. Phone: 613-737-8187; Fax 613-737-8189; E-mail: ecrosby@magma.ca 
does it work as well as the direct laryngoscope? A failure to answer both questions in the affirmative would seemingly relegate the device to the trash-heap. A caveat, and an important one, would be to ensure that the evaluator has done the necessary groundwork (reading the product insert at a minimum) and has a sense of how it is intended that the instrument be used before declaring it to be non-viable. Some very useful devices (e.g., flexible and rigid fibreoptic endoscopes) have flatter learning curves - it is important to ensure that similar challenging devices are not prematurely dismissed as having no utility when the truth might be that the evaluator has not yet achieved technical facility with it. It is difficult to critically evaluate some reports which may conclude negatively about particular devices because detailed information related to the evaluators is either not included in the text or if the information provided suggests that the evaluators may have had limited experience with the devices. ${ }^{10,11}$

Of the studies published assessing the effectiveness of new techniques and tools applied in the management of difficult airways, the best and most useful report on patients who actually possess a difficult airway. ${ }^{12,13}$ These papers are extremely relevant to clinicians as they provide information as to what might be expected and achieved by experienced users in the real world. Additionally, if the studies involve enough subjects, they may identify sub-populations for whom the technique might be or might not be particularly usefull. ${ }^{13}$ Unfortunately, these studies are tedious and time-consuming to carry out because of the difficulty involved in recruiting large numbers of patients with uncommon conditions.

An alternate strategy is to simulate a difficult airway in normal patients and then to evaluate tools and techniques under a challenging illusion. We have identified patient characteristics (and environmental factors) which predispose to difficult laryngoscopy and/or tracheal intubation. For example, we know that the combination of limited neck movement and limited mouth opening (Mallampati 3/4) is a powerful predictor of difficult laryngoscopy. Placing a hard cervical collar on a patient limits neck flexion, head extension and mouth opening and creates a model replicating the above combination this model approximates a form of a difficult airway - the anterior larynx. ${ }^{11,14}$ A "true" Grade 3 laryngoscopy is very common in this simulation and it is likely that it can be used to accurately assess tools and techniques advocated for difficult laryngoscopy. Conclusions regarding the utility of the tools and techniques assessed with this model are likely to be relevant provided information is relayed as to the experience level of the evaluators with the equipment being assessed.
Similarly, the use of in-line immobilization in normal patients, to simulate management of the airway in the setting of traumatic injury, also likely sufficiently replicates clinical reality. ${ }^{15,16}$ It also likely allows for accurate conclusions regarding the utility of the assessed tools and techniques in the real world. Assuming that the equipment has been properly maintained and that the practitioner is experienced in its use, it should be possible to replicate the findings of such publications in clinical practice. The reader should be attuned to the fact that certain elements of trauma care have not been evaluated in such simulations. For example, even though the lighted stylet is demonstrably highly effective in such scenarios, the presence of copious amounts of blood in the airway may compromise its utility in a given patient and such factors are not generally accounted for in simulation studies.

Agrò et al. used another model employed by others in airway management research.,17 Using a direct laryngoscope, they exposed the larynx. Then, by reducing traction, they allowed the epiglottis to settle posteriorly, thus obscuring the laryngeal inlet from view. Although this model may replicate a true Grade 3 laryngoscopy, it is not clear that it does. In the earlier models discussed, the larynx is actually anterior to the line of view. In the latter model, an epiglottic curtain hangs in the line of view, but laryngeal inlet is not as anteriorly deviated as it would be in the former scenarios. Additionally, the concurrent use of the second instrument may effect anatomic changes which may improve (or worsen) the performance of the instrument (Trachlight ${ }^{\mathrm{TM}}$ ) being subjected to evaluation. We are left somewhat unsure as to how to interpret the findings as the model is problematic and the technique does not mirror that normally employed with the tool being evaluated.

Simulation is likely to become an increasingly prevalent and important part of airway training and simulation studies are also likely to be presented to Journal readers more commonly than has been the case in the past. Readers need a strategy to allow for critical appraisal of such studies so that they may draw meaningful and relevant conclusions regarding the utility of the devices and techniques in their own practice. At a minimum, readers should be able to answer the following questions after reading the report. Did the authors identify the level of experience of the evaluators and validate their expertise? Does the model replicate the reality of the simulated scenario and if not, are the deviations important? Finally, was the tool used in a manner that could be construed as conventional or were there aspects of the technique that suf- 
ficiently differed from convention so as to make interpretation of the findings difficult or impossible?

\section{La simulation de l'intu- bation difficile - jusqu'où s'approche-t- on de la réalité ?}

Dans le présent numéro du Journal, Agrò et coll. présentent les résultats de leur recherche clinique sur l'évaluation de l'usage du stylet lumineux Trachlight ${ }^{\mathrm{TM}}$ pendant la simulation d'une intubation difficile. ${ }^{1}$ Ils concluent que le Trachlight ${ }^{\mathrm{TM}}$ est un outil sûr et efficace appliqué à la prise en charge de patients chez qui on a simulé une intubation difficile. La simulation est réalisée en utilisant la laryngoscopie directe pour créer une vue de classe 3 et, simultanément, le Trachlight ${ }^{\mathrm{TM}}$ pour faciliter l'intubation endotrachéale. C'est une des nombreuses études qui font état de l'évaluation du rôle d'une nouvelle technologie pour l'intubation difficile. Dans ces articles, les problèmes d'intubation sont parfois réels, mais le plus souvent simulés. Le lien à faire entre ces publications et la pratique clinique n'est pas toujours évident.

La conduite à adopter pour l'intubation relève d'un exercice à la fois cognitif et technique. En clair, le médecin doit pouvoir pressentir ce qui est approprié dans des circonstances données, c'est l'aspect cognitif. Cela sous-entend une reconnaissance et une intégration de la situation clinique et la mise en œuvre subséquente d'une stratégie clinique ciblée pour être efficace dans le scénario déterminé. À un certain moment de l'intervention, le processus devient surtout technique et il faut être rapide et efficace. Les éléments de l'intervention technique doivent avoir été isolés et pratiqués - c'est la partie technique de notre spécialité.

Les appareils d'entraînement et les simulations de patient sont utilisés pour l'acquisition de nouvelles compétences en intubation, pour l'évaluation de nouveaux outils et techniques et pour la réévaluation d'anciens dispositifs et stratégies de contrôle des voies aériennes. Leur rôle dans la formation semble plus important qu'avant. Pour diverses raisons, y compris la réduction des heures de travail et l'augmentation du nombre de sessions didactiques, les stagiaires passent moins de temps en salle d'opération et soignent moins de patients. ${ }^{2}$ Des conditions occasionnelles, comme une intubation difficile, vont donc se présenter moins souvent. Certaines données suggèrent aussi que les nouveaux outils ne soient pas largement, ni fréquemment, utilisés par les professeurs cliniques ; ${ }^{3,4}$ ces derniers pourraient hésiter à recevoir des stagiaires qui vont "réaliser des expériences avec des patients qui ne tireront aucun bénéfice de leur participation à la formation médicale et pourraient, en fait, subir des complications pendant ces sessions." ${ }^{5}$ L'usage répandu du masque laryngé a aussi réduit les occasions de pratiquer d'autres interventions sur les voies aériennes et, donc le niveau d'expérience des stagiaires. Pour ces raisons, et bien d'autres, il faut maintenant faciliter et concentrer l'expérience de formation; le matériel d'entraînement et les simulations de patients sont tout indiqués.

Cela ne fait aucun doute que l'usage d'appareils pour la formation à l'intubation constitue une stratégie efficace de développement et d'amélioration des compétences techniques reliées au contrôle des voies aériennes. Les habiletés de base, et même avancées, peuvent être acquises et pratiquées sur des modèles avant d'être utilisées chez un patient. Parmi les appareils utiles, il y a les mannequins d'intubation pour la laryngoscopie directe et les modèles mécaniques d'endoscopie flexible. Au cours des sessions de formation, les possibilités d'intervention sont illimitées, les répétitions peuvent l'être également et les erreurs n'ont pas de conséquences malheureuses. La répétition est importante, car plus de cent essais peuvent être nécessaires pour obtenir un taux de réussite fiable pendant l'apprentissage des interventions en intubation. ${ }^{6,7} \mathrm{Il}$ en faut parfois davantage pour les interventions jugées difficiles. ${ }^{8}$ Il existe également des données significatives concernant l'hypothèse qui veut que l'acquisition d'habiletés techniques soit facilitée par l'usage d'un programme de formation progressif avec du matériel d'intubation et des simulations de patients ; les meilleurs résultats sont obtenus lorsque ces compétences sont appliquées ensuite aux patients. Les stagiaires qui expérimentent cette formation progressive ont de meilleurs taux de réussite qu'avec une forme traditionnelle : observer un cas, faire un essai. ${ }^{9}$

Dans le but de déterminer l'utilité de nouveaux outils d'intubation, il semble qu'on continuera de compter sur les essais chez des patients comme sujets témoins. Dans ce contexte, il n'y a habituellement pas de simulation, mais on doit se poser plutôt deux questions bien simples, auxquelles on espère pouvoir répondre : 1) est-ce que l'appareil fonctionne ? et 2) est-il comparable à la laryngoscopie directe ? Un défaut de répondre affirmativement à ces questions 
pourrait vraisemblablement reléguer l'appareil au rebut. Une mise en garde, sérieuse, serait de s'assurer que l'évaluateur a procédé au travail préparatoire, au moins lire la fiche technique, et qu'il a une idée de la façon d'utiliser l'instrument avant de le déclarer inviable. Certains appareils efficaces, comme les fibroscopes flexibles et rigides, présentent des courbes d'apprentissage prolongé. Il est donc important de vérifier si ces appareils, complexes en un sens, ne sont pas prématurément rejetés comme n'ayant aucune utilité alors qu'en vérité l'évaluateur n'a peut-être pas atteint le degré de dextérité technique nécessaire à son usage. C'est difficile de faire l'évaluation critique des articles qui présentent des conclusions négatives au sujet de dispositifs particuliers parce que des informations détaillées reliées aux évaluateurs ne sont pas inclues dans le texte ou parce que les renseignements fournis laissent croire que les évaluateurs n'ont qu'une expérience limitée des appareils. ${ }^{10,11}$

Les études qui portent sur des patients chez qui l'intubation est effectivement difficile sont les meilleures et les plus utiles pour l'évaluation des techniques et des outils utilisés dans ces circonstances. ${ }^{12,13}$ Ces articles sont très pertinents à la pratique clinique, car ils fournissent des informations sur ce qui peut se produire dans la réalité quotidienne et sur ce que des utilisateurs expérimentés peuvent alors réaliser. De plus, si les études comptent un nombre suffisant de sujets, elles peuvent dégager des sous-populations pour lesquelles la technique serait, ou non, particulièrement utile. ${ }^{13}$ Malheureusement, ces études sont fastidieuses et chronophages parce qu'il est difficile de recruter un grand nombre de patients présentant des conditions rares.

On peut également simuler une intubation difficile chez des patients normaux et évaluer ensuite les outils et les techniques dans ce contexte de défi-fiction. Nous connaissons les caractéristiques des patients et les facteurs environnementaux qui prédisposent à une laryngoscopie difficile et/ou à une intubation problématique. Ainsi, les limites combinées du mouvement du cou et d'ouverture de la bouche (Mallampati 3/4) sont un prédicteur puissant de laryngoscopie difficile. L'utilisation d'un collier cervical rigide limite la flexion du cou, l'extension de la tête et l'ouverture de la bouche et crée un modèle reproduisant la combinaison précitée - le modèle se rapproche d'une forme d'intubation difficile - le larynx antérieur. ${ }^{11,14}$ Une "véritable" laryngoscopie de classe 3 , très fréquente dans ce genre de simulation, peut servir apparemment à des études précises d'évaluation des outils et des techniques recommandés pour la laryngoscopie difficile. Ces études seront pertinentes à condition d'en diffuser les informations concluantes, de même que le niveau d'expérience des évaluateurs avec le matériel évalué.

De même, l'utilisation de l'immobilisation en ligne chez les patients normaux, pour simuler le contrôle des voies aériennes dans le cadre d'une lésion traumatique, reproduit aussi assez fidèlement la réalité clinique. ${ }^{15,16}$ En outre, elle fournit des conclusions précises sur l'utilité des outils et techniques évalués dans une situation réelle. Si on suppose que le matériel a été bien entretenu et que le médecin en a expérimenté l'usage, il devrait être possible de répéter en clinique les résultats des publications. Le lecteur doit garder en mémoire que certains éléments du traitement d'un traumatisme n'ont pas été évalués dans ces simulations. Par exemple, même si la grande efficacité du stylet lumineux a été démontrée dans de contexte, la présence d'une importante quantité de sang dans les voies aériennes pourrait compromettre son utilité pour un patient en particulier. Ce genre de facteurs est rarement considéré dans les études en simulation.

Agrò et coll. ont choisi un autre modèle déjà utilisé par d'autres chercheurs pour la prise en charge des voies aériennes. ${ }^{1,17}$ Ils ont exposé le larynx au moyen de la laryngoscopie directe. Puis, en réduisant la traction, ils ont permis à l'épiglotte de se poser postérieurement, ce qui a empêché la vision de l'ouverture du larynx. Quoique ce modèle puisse reproduire une laryngoscopie de véritable classe 3, ce n'est pas évident qu'il le fasse. Dans les modèles présentés auparavant, le larynx était en fait antérieur au champ de vision. Dans le dernier modèle, l'épiglotte forme un rideau suspendu dans le champ de vision, mais l'ouverture laryngée n'est pas déviée antérieurement comme c'était le cas dans les premiers scénarios. De plus, l'usage concurrent du second instrument peut créer des changements anatomiques qui pourraient améliorer, ou affecter, la performance de l'instrument $\left(\right.$ Trachlight ${ }^{\mathrm{TM}}$ ) évalué. En quelque sorte, nous ne savons pas comment interpréter les résultats, puisque le modèle est problématique et la technique d'utilisation ne modélise pas l'usage normal employé dans l'évaluation du matériel.

La simulation est appelée à se répandre et à devenir de plus en plus importante dans la formation à l'intubation. Les études de simulation seront sans doute également présentées plus souvent aux lecteurs du Journal. Les lecteurs ont besoin d'une stratégie qui leur permette de faire une évaluation critique de ces études de sorte qu'ils tirent des conclusions sensées et pertinentes sur l'utilité d'appareils et de techniques de leur propre pratique clinique. Les lecteurs devraient au moins pouvoir répondre aux questions suivantes après 
la lecture de l'article. Les auteurs ont-ils déterminé le niveau d'expérience des évaluateurs et validé leur compétence ? Le modèle reproduit-il la réalité du scénario simulé et, si non, les déviations sont-elles importantes ? Finalement, l'instrument a-t-il été utilisé de manière traditionnelle ou certains aspects de la technique ontils différé suffisamment du procédé que cela a rendu l'interprétation des résultats difficile ou impossible ?

\section{References}

1 Agrò F, Benumof JL, Carassiti M, Cataldo R, Gherardi $S$, Barzoi G. Efficacy of a combined technique using the Trachlight ${ }^{\mathrm{TM}}$ together with direct laryngoscopy under simulated difficult airway conditions in 350 anesthetized patients. Can J Anesth 2002; 49: 525.

2 Duncan $P G$, Cohen $M M$, rip R. Clinical experiences associated with anesthesia training. Ann R Coll Phys Surg Can 1993; 26: 363-7.

3 Rose DK, Cohen MM. The airway: problems and predictions in 18,500 patients. Can J Anaesth 1994; 41: 372-83.

4 Rosenblatt WH, Wagner PJ, Ovassapian A, Kain ZN. Practice patterns in managing the difficult airway by anesthesiologists in the United States. Anesth Analg 1998; 87: 153-7.

5 Goldberg JS, Bernard AC, Marks RJ, Sladen RN. Simulation technique for difficult intubation: teaching tool or new hazard? J Clin Anesth 1990; 2: 21-6.

6 Konrad C, Schüpfer G, Weitlisbach M, Gerber $H$. Learning manual skills in anesthesiology: is there a recommended number of cases for anesthetic procedures? Anesth Analg 1998; 86: 635-9.

7 Kopacz DJ, Neal JM, Pollock JE. The regional anesthesia "learning curve". What is the minimum number of epidural and spinal blocks to reach consistency? Reg Anesth 1996; 21: 182-90.

8 Cass OW, Freeman ML, Peine CJ, Zera RT, Onstad GR. Objective evaluation of endoscopy skills during training. Ann Int Med 1993; 118: 40-4.

9 Ovassapian A, Yelich SJ, Dykes MHM, Golman ME. Learning fibreoptic intubation: use of simulators v. traditional teaching. Br J Anaesth 1988; 61: 217-20.

10 Fridrich P, Frass M, Krenn CG, Weinstabl C, Benumof $J L$, Krafft P. The Upsherscope ${ }^{\mathrm{TM}}$ in routine and difficult airway management: a randomized, controlled clinical trial. Anesth Analg 1997; 85: 1377-81.

11 MacQuarrie K, Hung OR, Law JA. Tracheal intubation using a Bullard laryngoscope for patients with a simulated difficult airway. Can J Anesth 1999; 46: 760-5.

12 Carr R, Reyford H, Belani K, Boufflers E, KrivosicHorber R, Palabnink R. Evaluation of the Augustine Guide $^{\mathrm{TM}}$ for difficult tracheal intubation. Can J Anaesth 1995; 42: 1171-5.
13 Hung OR, Pytka S, Morris I, Murphy M, Stewart RD. Lightwand intubation: II - clinical trial of a new lightwand for tracheal intubation in patients with difficult airways. Can J Anaesth 1995; 42: 826-30.

14 Gabbott $D A$. Laryngoscopy using the McCoy laryngoscope after application of a cervical collar. Anaesthesia 1996; 51: 812-4.

15 Shulman GB, Connelly NR. A comparison of the Bullard laryngoscope versus the flexible fiberoptic bronchoscope during intubation in patients afforded inline stabilization. J Clin Anesth 2001; 13: 182-5.

16 Laurent SC, de Melo AE, Alexander-Williams JM. The use of the McCoy laryngoscope in patients with simulated cervical spine injuries. Anaesthesia 1996; 51: 74-5.

17 Gataure PS, Vaughan RS, Latto IP. Simulated difficult intubation. Comparison of the gum elastic bougie and the stylet. Anaesthesia 1996; 51: 935-8. 